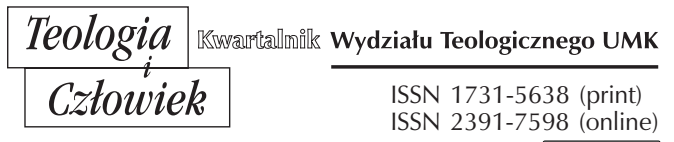

(ब) $\odot \odot$

46(2019)2, ss. 133-149

KS. ROBERT KACZOROWSKI

\title{
PIEŚNI RELIGIJNE OTTONA MIECZYSŁAWA ŻUKOWSKIEGO (1867-1942) POCHODZĄCE Z ZESZYTU X „ŚPIEWÓW KOŚCIELNYCH W UKŁADZIE NA JEDEN, DWA I CZTERY GŁOSY MIESZANE Z TOWARZYSZENIEM ORGANÓW LUB HARMONIUM" - PROBLEMATYKA TEOLOGICZNA I ZAGADNIENIA MUZYCZNE
}

DOI: http://dx.doi.org/10.12775/TiCz.2019.019

Streszczenie. Niniejszy artykuł jest omówieniem sześciu pieśni religijnych, opublikowanych przez kompozytora Ottona Mieczysława Żukowskiego (1867-1942) w zeszycie X pt. „Śpiewy kościelne w układzie na jeden, dwa i cztery głosy mieszane z towarzyszeniem organów lub harmonium”. Są to następujące utwory: Modlitwa; Pozostań z nami; Królowo niebios; Zostań z nami Panie; Matko Bolesna; O Jezu Chryste. Pieśni te są przeznaczone do śpiewania przez głos solowy przy akompaniamencie organów. Żukowski skomponował utwory do tekstów poetyckich współczesnych sobie autorów. Istotne znaczenie tych utworów polega na tym, że wykonywane podczas liturgii lub w czasie nabożeństw pozaliturgicznych stawały się śpiewaną katechezą w czasach, gdy dostęp do systematycznej nauki religii był utrudniony. Ich dodatkowym atutem jest również to, że napisane w języku polskim, były zrozumiałe dla uczestników liturgii odprawianej po łacinie. W wymiarze semantycznym pieśni uczyły o Bogu w Trójcy Świętej, wyrażały wiarę w Bożą Opatrzność, podkreślały prawdziwą obecność Jezusa pod postaciami eucharystycznymi, akcentowały osobę Maryi w dziele zbawienia. 
Słowa kluczowe: pieśń religijna; polskość; tożsamość religijna; katolicyzm; Otton Mieczysław Żukowski.

Summary. Religious songs of Otto Mieczysław Żukowski (1867-1942) from the Volume 10 „Liturgical Chants for One, Two and Four Mixed Voices to the Accompaniment of Pipe Organs or Harmonium" - theological problems and issues musical. In the presented article the author discusses six religious songs of Otton Mieczysław Żukowski (1867-1942) of the Volume 10 - „Śpiewy kościelne w układzie na jeden, dwa i cztery głosy mieszane z towarzyszeniem organów lub harmonium” [„Liturgical Chants for One, Two and Four Mixed Voices to the Accompaniment of Pipe Organs or Harmonium"]. The songs include: Modlitwa [The Prayer]; Pozostań z nami [Stay with us]; Królowo niebios [The Queen of Heaven]; Zostań z nami Panie [Lord Stay with us]; Matko Bolesna [Sorrowful Mother]; O Jezu Chryste [Oh Jesus Christ]. They are songs to be performed by soloists to the accompaniment of pipe organs. Żukowski composed songs to the poetical texts of authors contemporary to him. The songs were important, as performed during the liturgy or during the non-liturgical services, they have became catechesis to be sung in the times of limited access to systematic religious education. Moreover, as they were written in the Polish language, they could be understood by the participants of Latin liturgy. In terms of semantic meaning, the songs have provided the knowledge of God in the Holy Trinity, expressed the faith in the Divine Providence, highlighted the true presence of Jesus in the sacramental forms and emphasized the person of Mary in the act of salvation.

Keywords: Religious song; Polishness; national identity; Catholicism; Otton Mieczysław Żukowski.

\section{WSTĘP}

Otton Mieczysław Żukowski (1867-1942) urodził się w Bełzie nad rzeką Sołokiją (miasto to do 1951 roku pozostawało w granicach Polski, dzisiaj należy do Ukrainy). Większą część życia spędził w Czerniowcach, w północnej Bukowinie, gdzie po zakończonej edukacji powszechnej i muzycznej w tamtejszym seminarium nauczycielskim został suplentem, czyli zastępcą zatrudnionego na etacie nauczyciela. Uczył nadobowiązkowego języka polskiego, a od 1904 roku był profesorem seminarium nauczycielskiego w Cieszynie. Języka polskiego uczył również w państwowym gimnazjum. Pełnił także funkcję krajowego inspektora szkół polskich na Bukowinie ${ }^{1}$.

${ }^{1}$ Zob. R. Kaczorowski, Pieśni maryjne Ottona Mieczysława Żukowskiego, Wydawnictwo „Bernardinum”, Pelplin 2011; R. Kaczorowski, Pieśni ku czci Matki Bożej Ottona 
Otton Mieczysław Żukowski był również kompozytorem. Pozostawił po sobie wiele utworów wokalno-instrumentalnych - religijnych i świeckich oraz niezliczoną ilość opracowań pieśni. Jego aktywność na polu muzycznym wyrastała $\mathrm{z}$ wyrazistych przekonań, które „można wyrazić dwoma słowami: patriotyzm i wiara. Twórczość swą złożył więc Otton Mieczysław na ołtarzu walki o wolną i niepodległą Polskę, o miejsce języka polskiego w życiu publicznym, o historyczną świadomość Polaków oraz o uszanowanie wiary ojców i religii katolickiej”2.

W tak zarysowanym kontekście jawi się główny problem niniejszego artykułu, którego celem jest próba opisania sześciu pieśni religijnych, pochodzących z zeszytu X „Śpiewów kościelnych w układzie na jeden, dwa i cztery głosy mieszane z towarzyszeniem organów lub harmonium" w kontekście zagadnień teologicznych oraz muzycznych.

\section{REZENTACJA MATERIAŁU ŹRÓDŁOWEGO}

Wiele utworów religijnych Otton Mieczysław Żukowski wydawał w postaci zeszytów zatytułowanych „Śpiewy kościelne w układzie na jeden, dwa i cztery głosy mieszane z towarzyszeniem organów lub harmonium”. Publikował je „Składzie głównym w księgarni A. Piwarskiego i Ski”3 $^{\mathrm{k}}$ Krakowie. Żaden z zeszytów nie posiada jednak roku wydania.

W Bibliotece Narodowej w Warszawie znajduje się kilka takich zeszytów kompozytora, na przykład zeszyty VI, VII i IX . W dostępnych

Mieczysława Żukowskiego oraz ich miejsce w literaturze wokalnej, w: Musica Vocale. Sacrum i profanum w muzyce wokalnej - studium przypadku, red. R. Minkiewicz, Wydawnictwo Akademii Muzycznej w Gdańsku, Gdańsk 2014, s. 59-73; R. Kaczorowski, Zachowane msze Ottona Mieczysława Żukowskiego jako przejaw troski o polskość. Zagadnienia semantyczne i muzyczne, „Studia Gdańskie”, t. XXXVIII, Gdańsk-Oliwa 2016, s. 101-121; R. Kaczorowski, Siedem pieśni religijnych Ottona Mieczysława Żukowskiego (1867-1942) w kontekście zagadnień semantycznych i muzycznych, „Poznańskie Studia Teologiczne” 31 (2017), s. 259-274.

2 Zob. R. Kaczorowski, Tekst dołączony do płyty CD pt. „Otton Mieczysław Żukowski. Opera omnia religiosa 1”, wyd. Acte Préalable AP0288 (2013), s. 5.

${ }^{3}$ Informacja zawarta na stronie tytułowej.

${ }^{4}$ Katalogi Biblioteki Narodowej, http://katalogi.bn.org.pl/iii/encore/search/C Sotto\%20mieczys\%C5\%82aw\%20\%C5\%BCukowski_P4_Orightresult_U_X0?lan$\mathrm{g}=$ pol\&suite=cobalt [dostęp: 23.03.2018]. 
katalogach napisano, że publikacje te ukazały się około 1920 roku5. Wydaje się, że taką samą proweniencję można przyjąć odnośnie do zeszytu $\mathrm{X}$. Trzeba też podkreślić, że ów zeszyt nie figuruje w zasobach Biblioteki Narodowej; piszący te słowa jego kopię otrzymał od wnuczki kompozytora, Zofii Bajda ${ }^{6}$.

Zeszyt X zawiera sześć pieśni autorstwa Ottona Mieczysława Żukowskiego. Mają one następujące tytuły: Modlitwa; Pozostań z nami; Królowo niebios; Zostań z nami Panie; Matko Bolesna; O Jezu Chryste. Wszystkie pieśni są przeznaczone do śpiewania w jednogłosie przy akompaniamencie organów.

Poniższe tabele zawierają podstawowe informacje o utworach, ich opis formalny oraz budowę.

Tabela 1. Podstawowe informacje o utworach

\begin{tabular}{|c|c|c|c|c|}
\hline Lp. & Tytuł pieśni & Strony & Liczba taktów & Autor słów \\
\hline 1 & Modlitwa $a^{\mathrm{a}}$ & $2-3$ & 28 & ks. Mateusz Jeż \\
\hline 2 & Pozostań z nami ${ }^{\mathrm{b}}$ & $4-5$ & 40 & Stefania Dołżycka \\
\hline 3 & Królowo niebios ${ }^{c}$ & $6-7$ & 69 & $\begin{array}{l}\text { ks. Tadeusz } \\
\text { Karyłowski }\end{array}$ \\
\hline 4 & Zostań z nami Panie ${ }^{\mathrm{d}}$ & $8-9$ & 36 & ks. Mateusz Jeż \\
\hline 5 & Matko Bolesna ${ }^{\mathrm{e}}$ & $9-10$ & 36 & nieznany \\
\hline 6 & O Jezu Chryste & 11 & 41 & $\begin{array}{l}\text { ks. Franciszek } \\
\text { Błotnicki }\end{array}$ \\
\hline
\end{tabular}

a W ramach cyklu „Otton Mieczysław Żukowski. Opera omnia religiosa” na płycie nr 2 AP0343 (2015) zarejestrowano między innymi wszystkie utwory z zeszytu X. Wykonawcami pieśni pt. Modlitwa są: Paweł Pecuszok - tenor, Ewa Rytel - organy.

b „Otton Mieczysław Żukowski. Opera omnia religiosa2 ” AP0343 (2015). Wykonawcy: Paweł Pecuszok - tenor, Ewa Rytel - organy.

c „Otton Mieczysław Żukowski. Opera omnia religiosa2” AP0343 (2015). Wykonawcy: Ewa Wolak - alt, Ewa Rytel - organy.

d „Otton Mieczysław Żukowski. Opera omnia religiosa2 ” AP0343 (2015). Wykonawcy: Katarzyna Dondalska - sopran, Ewa Rytel - organy.

e „Otton Mieczysław Żukowski. Opera omnia religiosa2 ” AP0343 (2015). Wykonawcy: Paweł Pecuszok - tenor, Ewa Rytel - organy.

f „Otton Mieczysław Żukowski. Opera omnia religiosa2 ” AP0343 (2015). Wykonawcy: Robert Kaczorowski - baryton, Ewa Rytel - organy.

${ }^{5}$ Ibidem.

${ }^{6}$ Zob. Otton Mieczysław Żukowski - nieznane fakty z życia kompozytora i jego rodziny. Z wnuczka kompozytora Zofia Bajda rozmawia Robert Kaczorowski, „Muzyka21”, Rok XVI nr 1(174), styczeń 2015, s. 36-37. 
Tabela 2. Opis formalny utworów

\begin{tabular}{|c|c|c|c|c|c|}
\hline Lp. & Tytuł pieśni & Metrum & Tonacja & Tempo & Ambitus melodii \\
\hline 1 & Modlitwa & $3 / 4$ & a-moll & Assai lento & $e^{1}-f^{2}$ \\
\hline 2 & Pozostań z nami & $\mathrm{C}$ & Des-dur & Zwolna, serdecznie & $e s^{1}-f^{2}$ \\
\hline 3 & Królowo niebios & $\mathbb{C}$ & C-dur & $\begin{array}{l}\text { Spokojnie, } \\
\text { z wyrazem }\end{array}$ & $d^{1}-f^{2}$ \\
\hline 4 & $\begin{array}{c}\text { Zostań z nami } \\
\text { Panie }\end{array}$ & $\mathrm{C}$ & F-dur & Andante & $\mathrm{f}^{1}-\mathrm{f}^{2}$ \\
\hline 5 & Matko Bolesna & $3 / 4$ & F-dur & Moderato & $\mathrm{d}^{1}-\mathrm{e}^{2}$ \\
\hline 6 & O Jezu Chryste & $3 / 4$ & F-dur & Andante & $\mathrm{c}^{1}-\mathrm{es}^{2}$ \\
\hline
\end{tabular}

Tabela 3. Budowa utworów

\begin{tabular}{|c|c|c|}
\hline Lp. & Tytuł pieśni & Budowa utworów \\
\hline 1 & Modlitwa & $\begin{array}{c}\text { Wstęp organowy (takty 1-2) } \\
\text { Część A (takty 3-10) } \\
\text { Część B (takty 11-20) } \\
\text { Część C (takty 21-24) } \\
\text { Zakończenie organowe (takty 24-28) }\end{array}$ \\
\hline 2 & Pozostań z nami & $\begin{array}{c}\text { Część A (takty 1-14) } \\
\text { Łącznik organowy (takty 15-16) } \\
\text { Część B (takty 17-35) } \\
\text { Zakończenie organowe (takty 36-40) }\end{array}$ \\
\hline 3 & Królowo niebios & $\begin{array}{c}\text { Wstęp organowy (takty 1-8) } \\
\text { Część A (takty 9-24) } \\
\text { Łącznik organowy (takty 25-27) } \\
\text { Część B (takty 28-43) } \\
\text { Część C (takty 44-69) }\end{array}$ \\
\hline 4 & Zostań z nami Panie & $\begin{array}{l}\text { Część A (takty 1-16) } \\
\text { Część B (takty 17-36) }\end{array}$ \\
\hline 5 & Matko Bolesna & $\begin{array}{l}\text { Wstęp organowy (takty 1-4) } \\
\text { Część A (takty 5-20) } \\
\text { Część B (takty 21-36) }\end{array}$ \\
\hline 6 & O Jezu Chryste & $\begin{array}{c}\text { Część A (takty } 1-17) \\
\text { Łącznik organowy (takty 18-21) } \\
\text { Część B (takty 22-41) }\end{array}$ \\
\hline
\end{tabular}

\section{PROBLEMATYKA TEOLOGICZNA PIEŚNI}

Spośród sześciu pieśni, wchodzących w skład zeszytu X „Śpiewów kościelnych w układzie na jeden, dwa i cztery głosy mieszane z towarzyszeniem organów lub harmonium", cztery skierowane są do Pana Jezusa, a dwie do Matki Boskiej. 
W utworze pt. Modlitwa podmiot liryczny z głęboką wiarą zwraca się do Chrystusa. Czyni to w szczególny sposób zawsze wówczas, gdy jest mu ciężko, gdy pojawiają się trudne sytuacje życiowe, gdy przytłaczają troski codzienności. Człowiek ma świadomość tego, że Bóg jest Tym, który nigdy nie opuści swojego stworzenia. Bóg obecny w Panu Jezusie zawsze jest przy osobie potrzebującej. To On obdarza łaską zasmuconą duszę. To On pociesza tych, którzy czują się sierotami na tym świecie. A świat, w którym żyje człowiek „chłodem odpycha”, gdyż króluje w nim fałsz i nieuczciwość. Podmiot dostrzega również marność wszystkich światowych uciech. Bardzo wyraźnie dostrzega jednocześnie swój grzech i swe grzeszne czyny. Ich wspominanie budzi wręcz „rozpacz”. Wtedy przed jego oczami pojawia się „Krzyż” - zwycięski znak zbawienia. Człowiek wyznaje wiarę, że Jezus jest „Zbawcą” i „Bogiem”; wyznaje, że Jezus miłuje człowieka mimo wszystko, mimo grzechów i upadków. Jezus staje się jedyną nadzieją. Dlatego w pokorze podmiot liryczny wyciąga swe ręce po „święte łaski”, których udzielić może tylko Bóg. Prosi też o wewnętrzną pociechę i dar wiary, z którą chce iść przez życie.

Pieśń Pozostań z nami przywołuje na myśl opisaną na kartach Ewangelii według św. Łukasza scenę, gdy po zmartwychwstaniu Chrystusa dwaj Jego uczniowie udali się w drogę do Emaus. Część drogi spędzili u boku Nieznajomego, który tłumaczył im słowa Pisma Świętego o mającym cierpieć i umrzeć Mesjaszu. Uczniowie tak bardzo chcieli wsłuchiwać się w Jego słowa, że - jak zapisał św. Łukasz - „przymusili Go”, aby został z nimi, „gdyż ma się ku wieczorowi”. Apostołowie rozpoznali Zmartwychwstałego Pana dopiero wówczas, gdy zaczął łamać i rozdawać im chleb... (por. Łk 24, 13-35).

Ta sama prośba, aby Chrystus Pan pozostał między swoimi pojawia się w pieśni Pozostań z nami. Podmiot liryczny, który występuje w liczbie mnogiej, błaga, by Jezus „zstąpił z wysokości”, przyjął schronienie w ludzkich sercach i obdarzał swymi łaskami człowieczą dolę i człowieczy los. Obecność Chrystusa najpełniej się objawia w znakach eucharystycznych. Dlatego wierny lud prosi swego Pana, by już na wieki, na zawsze pozostał „pod znakiem chleba białej Hostyi”. Autorka poetyckiego tekstu określa bowiem współczesne sobie pokolenie mianem „ginącego kwiatu”, który potrzebuje ożywienia i uprawy. Tę odnowę rodzaju ludzkiego może dać tylko Bóg obecny w Eucharystii. 
Podmiot liryczny zwraca uwagę, że ludzie są jak „wygnańcy ziemi”, którzy swój ciężki los znoszą z coraz większym trudem. Dlatego też do Jezusa, „Króla miłości”, skierowana jest prośba, aby tę trudną dolę przemienił w „raj nadziemski”. Jednocześnie wypowiedziane są słowa modlitwy, aby ziemia wydawała wreszcie plony, aby na ziemi nie było głodu i aby ludzie mieli co jeść. Modlitwa obejmuje również sferę życia duchowego: podmiot liryczny prosi, aby Jezus Chrystus, „Syn Maryi”, towarzyszył człowiekowi w ostatnich chwilach życia i wprowadził do królestwa życia wiecznego.

Królowo niebios to pieśń skierowana do Matki Najświętszej. Podmiot liryczny prosi $\mathrm{w}$ tym utworze, aby Maryja stała się pocieszycielką w czasach, w których świat proponuje tylko to, co złe. Maryja może więc stać się mocą $\mathrm{w}$ walce $\mathrm{z}$ przeciwnościami życia. Podczas gdy człowiek jest smutny, zmartwiony i przygnębiony, „Królowa niebios” jest „promienna, świetlana”. Dlatego w postawie pokory czciciel Maryi prosi, by Ona, Matka Jezusa, wszystkie ludzkie i ziemskie cierpienia zaniosła „przed stopy Pana”. Podmiot liryczny wspomina także swe młodzieńcze chwile, gdy przed obrazem Matki Bożej „zginał kolana”. Był wówczas „tak bardzo szczęśliwy”.

Zostań z nami Panie to tytuł kolejnej pieśni, której słowa - wydaje się - jakby były wypowiadane pod koniec ludzkiego życia, gdy nadchodzi jego kres. To wówczas człowiek ma czas na dokonanie analizy i podsumowania swojego życia. To wtedy pojawiają się „wspomnienia lat dziecięcych”, ale również "upadki i skazy” oraz "błędy i zawody” wieku dojrzałego. Właśnie z taką świadomością, z całym bagażem swojego życiowego doświadczenia podmiot liryczny prosi, aby Pan wciąż przy nim był, aby nie odchodził. Bo przecież Bóg - przekonuje autor poetyckiego tekstu - obiecał człowiekowi, że nigdy go nie zostawi i że zawsze będzie go miał w swojej opiece. Bóg przyobiecał również, że „zamieszka na wieki” pośród swoich. Ta obietnica spełnia się, gdy Jezus daje „Samego Siebie” w „królewskim darze”, jakim jest Komunia Święta. Jak wielki i niepojęty jest Bóg, że jest w stanie istnieć „pod nikłymi postaciami” chleba i wina! On przecież wciąż jest obecny w świętej Hostii na ołtarzu, aby wlewać nadzieję w człowieka i w ten sposób „słodzić jego ciężkie chwile” oraz „ziemskie wygnanie”. Dlatego podmiot liryczny w postawie głębokiej wiary prosi, aby Bóg nigdy człowieka nie opuścił. 
W pieśni Matko Bolesna podmiot liryczny prosi Maryję, by zwróciła swe oblicze na niedolę i nędzę człowieka. Bowiem tylko Ona wie, co to jest boleść i „skargi szloch”. Jej całe życie wypełnione było cierpieniem, a męka i śmierć Syna sprawiła, że jest Matką Siedmiu Boleści. Dlatego właśnie przed Jej obliczem człowiek korzy się „w proch” i prosi, by Maryja wejrzała na cierpienie człowieka, na jego łzy i ból. Podmiot liryczny błaga, aby Najświętsza Panienka uczyła, jak „cierpliwie znosić ból” i aby szczęśliwie prowadziła przez życiowe próby. Kolejne prośby kierowane do Pani świata związane są z sytuacjami, gdy człowiek poddawany jest pokusom i w jego duszy trwa „krwawy bój”. Błaga, by Maryja leczyła rany, zaś w serca wlewała „balsam niebiański”, który sprawiłby, że w duszy zapłonie „Bożej miłości żar”.

W pieśni O Jezu Chryste „znękany” życiem, walką i codziennością człowiek biegnie do Tego, który jest „Panem nad Pany”, prosząc Go o wewnętrzny spokój ducha. Świat bowiem daje tylko „ból i troski”. Ze szczerą wiarą podmiot liryczny biegnie „przed tron Boski” i wznosi wzrok ku niebu, ku Jezusowi, gdyż wie, że tylko u Niego odnajdzie „łask wielkich zdroje”. Tylko Jezus może ukoić skołatane serce i obdarzyć „szczęściem wiekuistym”. Dlatego człowiek całe swoje życie składa w ofierze Panu Bogu; oddaje $\mathrm{Mu}$ to, „Co cieszy”, jak i to, „Co rani”; ofiaruje to, „co jasne” oraz to, „co mgliste” $\mathrm{z}$ wiarą, że dobry Bóg wszystko to przyjmie i pobłogosławi.

\section{ZAGADNIENIA MUZYCZNE PIEŚNI}

Dokonując oglądu twórczości religijnej Ottona Mieczysława Żukowskiego, śmiało można stwierdzić, że kompozytor posiadł niezwykłą swobodę w tworzeniu nieskomplikowanych melodii, które zawsze przez słuchaczy odbierane są bardzo pozytywnie.

W kontekście zagadnień harmonicznych na uwagę zasługuje fakt, że Żukowski posługiwał się harmonią tonalną, wzbogaconą akordami wtrąconymi, zboczeniami modulacyjnymi, nierzadko łańcuchem akordów wtrąconych, dźwiękami przejściowymi czy alteracjami. Zastosowane przez kompozytora zjawiska harmoniczne sprawiają, że jego muzyka jest ciekawa i interesująca. 
Jako przykład warto zatrzymać się nad pieśnią O Jezu Chryste, celem bliższego omówienia harmonii tego utworu.

Stosując współczesne oznaczenia, plan harmoniczny powyższego utworu można przedstawić następująco.

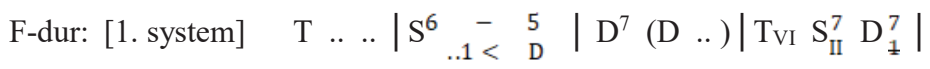

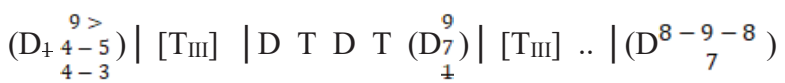

$\mathrm{T}$

T 5

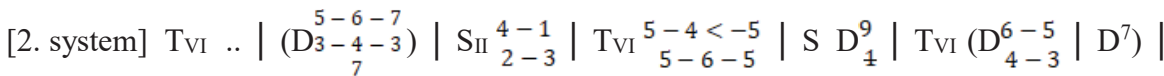

(D $\left.\mid \mathrm{D}_{5-6-5}^{7}\right)\left|\mathrm{S}_{\text {II }}^{2-1} \underset{1}{\left(\mathrm{D}_{7}^{9}\right)}\right|\left[\mathrm{T}_{\mathrm{III}}\right]|\mathrm{T}|$

$$
\mathrm{D}_{4-2-3}^{6-7}
$$

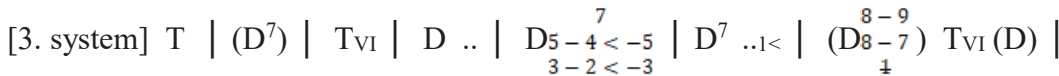

\begin{tabular}{l|lll|ll|l}
$4-3$ & TVI & D & T & D &. .7
\end{tabular}

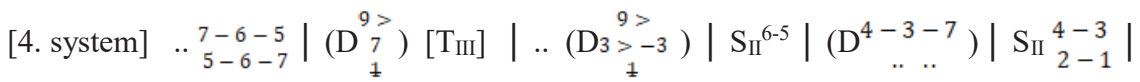

\begin{tabular}{ll|lll|ll|}
$\mathrm{S}$ & ${ }^{\circ} \mathrm{S}^{6}$ & $\mathrm{~T}$ & $\mathrm{D}^{7}$ &. & $\mathrm{~T}$
\end{tabular}

$\begin{array}{lll}7<-8 & 3 & 5\end{array}$ 
Trzeba stwierdzić, że Żukowski traktuje harmonię dość swobodnie. Dotyczy to między innymi pozostawiania tego samego akordu po kresce taktowej w następujących miejscach:

- pierwszy system: ostatni akord w takcie drugim i pierwszy akord w takcie trzecim (dominanta);

- drugi system: akord w takcie ósmym i akord w takcie dziewiątym (dominanta);

- drugi system: tonika w ostatnim takcie i tonika w pierwszym takcie trzeciego systemu;

- trzeci system: dominanta w czwartym takcie, dominanta w piątym takcie i dominanta w szóstym takcie;

- trzeci system: $\mathrm{T}_{\mathrm{VI}} \mathrm{w}$ ósmym takcie i powtórzony ten sam akord na pierwszą miarę taktu dziewiątego;

- trzeci system: dominanta w ostatnim takcie i ten sam akord w pierwszym takcie czwartego systemu).

Oczywiście należy też podkreślić, że nawet jeśli te same akordy trwają na przestrzeni kolejnego taktu bądź kilku taktów, to zmienia się ich pozycja i postać, pojawiają się dźwięki przejściowe, alteracje, dodawane są również septymy lub nony. Harmonia więc nie traci, a wręcz przeciwnie, zyskuje.

Z punktu widzenia współczesnej harmonii należałoby jednak unikać ruchu równoległego wszystkich głosów (drugi system: takty 5 i 10) oraz krzyżowania głosów (takt 5).

Swobodne podejście do harmonii widoczne jest również w zdwajaniu kwinty w tonice (pierwszy system, takt 6) oraz podwojeniu kwinty $\mathrm{w}_{\mathrm{VI}}$ (drugi system, takt 6).

Natomiast w ostatnim systemie, w takcie 7 pojawia się ukośne brzmienie półtonu między dźwiękami $d^{2} \mathrm{w}$ sopranie oraz des ${ }^{1} \mathrm{w}$ tenorze. Jest ono jednak złagodzone tym, że w tenorze dźwięk des zostaje osiągnięty jako obniżenie dźwięku $d$.

Na przykładzie opisywanego utworu widać również, że kompozytor poszukując ciekawych rozwiązań harmonicznych, stosował zabieg, który we współczesnej harmonii nazywa się wyrzutnią bądź elipsą. Występuje on wówczas, gdy wtrącona dominanta rozwiązuje się zwodniczo - w przypadku opisywanego utworu jest to ruch o sekundę do góry. Zjawisko to występuje czterokrotnie: 
- pierwszy system: takty 5 i 6 oraz takty 7 i 8 ;

- drugi system: takty 10 i 11;

- czwarty system: takt 2.

Zastosowana przez Żukowskiego wyrzutnia we wszystkich przypadkach dotyczy akordu E-dur jako dominanty (bez prymy, z noną małą i septymą małą) do tonacji a-moll. Za każdym razem akordem, na który faktycznie rozwiązuje się dominanta jest akord F-dur, czyli tonika tonacji głównej. Opisywane zjawisko graficznie przedstawia się następująco.

$\left(\begin{array}{c}9> \\ 7 \\ 1\end{array}\right)\left[\mathrm{T}_{\mathrm{III}}\right]$

$\mathrm{T}$

Mimo tego, że kompozytor cztery razy zastosował ten sam zabieg, za każdym razem zarówno postać i pozycja dominanty, jak i toniki jest inna.

Te zasygnalizowane jedynie właściwości języka muzycznego Ottona Mieczysława Żukowskiego sprawiają, że jego kompozycje, mimo niewielkich rozmiarów i pozornej prostoty, są utworami wymagającymi dla wykonawców i ciekawymi dla słuchających.

\section{ZAKOŃCZENIE}

Zważywszy na fakt, że na przełomie XIX i XX wieku dostęp do regularnej katechezy nie był powszechny, wykonywanie podczas liturgii lub w czasie nabożeństw pozaliturgicznych omawianych w niniejszym artykule pieśni, niewątpliwie odgrywało istotną rolę w utwierdzaniu wyznawanych prawd wiary katolickiej. Pieśni te bowiem, pomijając ich wartości poetyckie, były źródłem wielu katechizmowych treści i swoistym podręcznikiem przybliżającym rozumienie dogmatów Kościoła. I co w tym kontekście wydaje się istotne, to fakt, że prezentowane treści podawane były po polsku, czyli w zrozumiałym języku ojczystym.

Konkludując, omawiane pieśni zwracają uwagę między innymi na następujące zagadnienia:

- uczą, że Jezus jest pocieszycielem człowieka i to On rozdaje ludzkości swoje łaski (Modlitwa, Pozostań z nami, O Jezu Chryste), 
- przypominają, że w zjednoczeniu z Krzyżem Zbawiciela cierpienie człowieka nabiera wewnętrznego sensu (Modlitwa),

- zwracają uwagę na właściwie uformowane sumienie, które pomaga rozróżnić to, co jest dobre od tego, co jest złe (Modlitwa),

- uczą, że Jezus jest Zbawicielem i nadzieją człowieka (Modlitwa, O Jezu Chryste),

- podkreślają, że Jezus jest obecny w postaciach eucharystycznych (Pozostań z nami),

- edukują, że Jezus jest Synem Maryi Panny (Pozostań z nami),

- akcentują wiarę w życie wieczne (Pozostań z nami, O Jezu Chryste),

- eksponują prawdę, że Maryja jest pośredniczką między Bogiem a człowiekiem (Królowo niebios),

- wyrażają wiarę w Boską opatrzność (Zostań z nami Panie),

- przypominają o dokonującej się podczas każdej Mszy świętej ofierze (Zostań z nami Panie),

- uczą o realnej obecności Chrystusa w Eucharystii (Zostań z nami Panie),

- objaśniają, że Maryja jest Matką Boleściwą (Matko Bolesna),

- podkreślają, że Maryja współuczestniczyła w cierpieniach swego Syna (Matko Bolesna),

- podkreślają, że Maryja jest wzorem cierpliwości i zawierzenia Panu Bogu (Matko Bolesna),

- pokazują, że Maryja uczy wytrwałości w cierpieniu i próbach (Matko Bolesna),

- uświadamiają, że Jezus obdarza człowieka wewnętrznym pokojem (O Jezu Chryste).

- poprzez nazwanie Jezusa „Władcą” w pieśni Pozostań z nami wskazują również na charakterystyczny rys potrydenckiej religijności, która przez wieki kształtowała umysły wiernych (mysterium tremendum)

- natomiast skomponowane przez Ottona Mieczysława Żukowskiego melodie, z interesującą harmonią, niewątpliwie stały się skutecznym środkiem do przyswajania usłyszanych podczas śpiewu treści. 


\section{BIBLIOGRAFIA}

\section{Źródła}

\section{Archiwum prywatne autora}

Otton Mieczysław Żukowski, Śpiewy kościelne w układzie na jeden, dwa i cztery głosy mieszane z towarzyszeniem organów lub harmonium, zeszyt X, wyd. „Skład główny w księgarni A. Piwarskiego i Ski”, Kraków [b.r.w.].

\section{Internet}

Katalogi Biblioteki Narodowej, http://katalogi.bn.org.pl/iii/encore/search/C__Sotto\%20 mieczys\%C5\%82aw\%20\%C5\%BCukowski_P4_Orightresult_U_X0?lang=po1\&suite=cobalt [dostęp: 23.03.2018].

\section{Płyty CD}

„Otton Mieczysław Żukowski. Opera omnia religiosa 1”, wyd. Acte Préalable AP0288 (2013).

„Otton Mieczysław Żukowski. Opera omnia religiosa 2", wyd. Acte Préalable AP0343 (2015).

\section{Literatura}

Kaczorowski R., Pieśni ku czci Matki Bożej Ottona Mieczysława Żukowskiego oraz ich miejsce w literaturze wokalnej, w: Musica Vocale. Sacrum i profanum w muzyce wokalnej - studium przypadku, red. R. Minkiewicz, Wydawnictwo Akademii Muzycznej w Gdańsku, Gdańsk 2014, s. 59-73.

Kaczorowski R., Pieśni maryjne Ottona Mieczysława Żukowskiego, Wydawnictwo „Bernardinum”, Pelplin 2011.

Kaczorowski R., Siedem pieśni religijnych Ottona Mieczysława Żukowskiego (1867-1942) w kontekście zagadnień semantycznych i muzycznych, „Poznańskie Studia Teologiczne" 31 (2017), s. 259-274.

Kaczorowski R., Zachowane msze Ottona Mieczysława Żukowskiego jako przejaw troski o polskość. Zagadnienia semantyczne i muzyczne, „Studia Gdańskie”, t. XXXVIII, Gdańsk-Oliwa 2016, s. 101-121.

Otton Mieczysław Żukowski - nieznane fakty z życia kompozytora i jego rodziny. Z wnuczka kompozytora Zofią Bajda rozmawia Robert Kaczorowski, „Muzyka21”, Rok XVI nr 1 (174), styczeń 2015, s. 36-37. 


\section{ANEKS}

\section{Modlitwa}

Gdy smutek duszę mą ogarnie, gdy troski oczy me zamroczą, gdy mi sieroco na tym świecie, do Ciebie, Panie Jezu zwracam się ochoczo. Gdy świat mnie chłodem swym odpycha, kiedy mnie brzydzą uciech blaski, gdy jad spostrzegam w dnie kielicha, wyciągam ręce po Twe Jezu łaski, po święte łaski Twe Panie, Ty pociesz, Ty pociesz, ratuj, o ratuj nas!

Kiedy mnie dręczy me sumienie, gdy grzechy stają mi w pamięci, gdy budzi rozpacz ich wspomnienie, Twój Krzyż, o Jezu, Twe Boskie mnie serce nęci. Boś Ty mym Zbawcą, Tyś mym Bogiem, Ty mnie miłujesz, to mi starczy! Niech życie płynie swą koleją, Ty Panie jesteś mą nadzieją, Tyś mą nadzieją, Panie, mój Panie, Ty pociesz, Ty pociesz, ratuj, o ratuj nas!

\section{Pozostań z nami}

Pozostań z nami i przyjm schronienie, Królu miłości, bo dzień się chyli, noc kładzie cienie, zstąp z wysokości, na niwę serc, w niej zamieszkać chciej, użyźniaj ją, łask strugą zlej, błagamy Cię!

Pozostań z nami pod znakiem chleba białej Hostyi, bo zbrakło szat, ost wydaje gleba, Synu Maryi! Ożyw ginący kwiat, Twój lud, uchyl więc rąbka szat, ścisz głód, błagamy Cię!

Pozostań, prosim wygnańcy ziemi, 
Rozkoszy nieba, niech w raj nadziemski padół się zmieni, plon wyda gleba, a łza się wplecie w tęczy cudnej blask, zwiastunką będzie Bożych łask, błagamy Cię!

Pozostań z nami Władco na wieki w Hostji spowiciu, gdy czas przeminie zamknij powieki, oznacz kres życiu! Niech duch zwolniony dotrze bram i ujrzy Bóstwa pyszny chram, błagamy Cię!

\section{Królowo niebios}

Królowo niebios, stęsknioną myśl moją łaskawie pociesz tęczami rajskiemi, bo pośród świata tak pusto i źle mi, bo ludzie samą zgryzotą mnie poją.

W bój życia twardą opancerz mnie zbroją, ze serca oddal gryzący pył ziemi, spójrz smutny jestem, choć smugi złotemi uśmiechy słońca wiosenną ruń stroją.

Królowo niebios, promienna, świetlana, z poszeptem wiatru, co zrywa się z niwy ból cierpień moich przed stopy nieś Pana, ze łzą wspominam chłopięce porywy, gdym przed obrazem Twym zginał kolana, gdy w sercu byłem tak bardzo szczęśliwy.

\section{Zostań z nami Panie}

Dzień życia się nachylił.

Zmierzch zwolna nadchodzi, duch tonie w myśli wrażeń i obaw powodzi; wspomina lat dziecięcych niewinne obrazy, młodości swej niebacznej upadki i skazy, 
i wieku dojrzałego

błędy i zawody,

szukając wciąż dla siebie

ulgi i ochłody,

woła do Ciebie, Chryste,

$\mathrm{w}$ tym poważnym stanie

z serdecznych głębin swoich:

zostań z nami Panie!

Tyś przyrzekł nam, że z nami zamieszkasz na wieki, że nigdy nas ze Swojej nie puścisz opieki.

Przez miłość, której w świecie nikt równej nie wskaże, Samego Siebie dałeś w królewskim nam darze: pod nikłych Ty postaci żyjesz zasłonami w Hostji Przenajświętszej na ołtarzu z nami, by w ciężkich chwilach słodzić ziemskie nam wygnanie, z ufnością więc wołamy: zostań z nami Panie!

\section{Matko Bolesna}

Matko Bolesna Twe oko zwróć ku mojej nędzy, niedolę skróć, Ty znasz, co boleść, co skargi szloch, przed Tobą Matko korzę się w proch.

Tyś bowiem siedmiu doznała ran, kiedy na krzyżu konał nasz Pan.

Całe Twe życie bolesna nić; goryczy kielich musiałaś pić.

Spójrz na mą boleść co serce drze, jak łzy zraszają źrenice me. 
Ucz mnie cierpliwie znosić ból, prowadź przez próby do niebios pól.

Gdy w mojej duszy wre krwawy bój, Ty moje rany litośnie gój.

Wlej w nią balsamu niebiański dar miłości Bożej zapal w niej żar.

\section{O Jezu Chryste}

W życiowej walce bólem znękany, do Ciebie biegnę, Panie nad Pany, Ty mi spokoju dasz źródło czyste, o Jezu Chryste! o Jezu Chryste!

Świat mi ból tylko daje i troski, znękany biegnę przed tron Twój Boski, wzrok korny wznoszę w niebo gwiaździste, o Jezu Chryste! o Jezu Chryste!

U Ciebie znajdę łask wielkich zdroje, biedne ukoisz Ty serce moje i Ty mi szczęście dasz wiekuiste, o Jezu Chryste! o Jezu Chryste!

U stóp Twych składam życie me w dani, wszystko co cieszy, wszystko co rani, i to co jasne i to co mgliste, o Jezu Chryste! o Jezu Chryste! 